\title{
Flux and Permeation Behaviour of Ultrafiltration in Sugaring Out Cellulose Hydrolysate Solution: A Membrane Screening
}

\author{
Masniroszaime Md Zain, ${ }^{1}$ Abdul Wahab Mohammad ${ }^{1 *}$ and Nur Hanis Hayati Hairom ${ }^{2}$ \\ ${ }^{1}$ Department of Chemical and Process Engineering, Faculty of Engineering \\ and Built Environment, Universiti Kebangsaan Malaysia, Selangor, Malaysia \\ ${ }^{2}$ Department of Chemical Engineering Technology, Faculty of Engineering Technology, \\ Universiti Tun Hussein Onn Malaysia, Johor, Malaysia \\ ${ }^{*}$ Corresponding author: drawm@ukm.edu.my
}

Published online: 15 February 2017

To cite this article: Md Zain, M., Mohammad, A. W. \& Hairom, N. H. H. (2017). Flux and permeation behaviour of ultrafiltration in sugaring out cellulose hydrolysate solution: A membrane screening. J. Phys. Sci., 28(Supp. 1), 25-38, https://doi.org/10.21315/ jps2017.28.s1.2

To link to this article: https://doi.org/10.21315/jps2017.28.s1.2

\begin{abstract}
Cellulose hydrolysate ultrafiltration was investigated as in-situ separation of glucose while limiting the consumption of enzyme. Thus the high permeation of glucose through the membrane is one of the main criteria required in designing an efficient membrane reactor system. The performances of three commercial UF membranes (PES20, PA3 and PSF20) were compared in a stirred batch cell. Special attention was directed to the permeation of glucose and retention of enzyme of the cellulose hydrolysate. The effects of solution $\mathrm{pHs}$ and the presence of lignin on membrane fouling were evaluated. The results revealed that significant flux decline was obtained for PES20 and PSF20 membrane (44\% decline), but slight flux decline occurred for PA3 membrane (13\% decline). The permeation of glucose up to $90 \%$ was found to be higher for PA membrane. To mitigate fouling, it is appropriate to increase the negatively charge of the membrane surface through rising up the $\mathrm{pH}$ solution from the isoelectric point (IEP) of cellulose hydrolysate.
\end{abstract}

Keywords: Cellulose hydrolysate, ultrafiltration, glucose, fouling, membrane screening

\section{INTRODUCTION}

Lignocelluloses biomass has been recognised as an alternative to fossil fuels in producing bioproducts and bioenergy by transforming the native cellulose and hemicelluloses to fermentable sugar for fermentation. ${ }^{1-3}$ Several bioconversion 
schemes have been proposed based on microbial fermentation which typically requires pretreatment and enzymatic hydrolysis as the prerequisite steps. ${ }^{4,5}$ The outlet streams from the pretreatment and enzymatic hydrolysis contain dilute sugars, along with excess components such as enzymes and biomass. These dilute fermentable sugars, which are the products from the enzymatic hydrolysis, may inhibit enzyme significantly, hence plaguing the rate of enzymatic degradation. ${ }^{6,7}$ To overcome these deficiencies, the removal of the sugars from the hydrolysate by membrane process can contribute towards not only in improving the hydrolysis but also in recovering the used enzymes. This can help to decrease the cost of enzymatic hydrolysis by reducing the usage of enzyme by recycling. ${ }^{8,9}$

Recent review on literature has shown increasing number of research works in the last decade with respect to the application of ultrafiltration (UF) membrane process in biomass-derived process due to its vital part in the separation and purification of the bioproducts and biofuels. ${ }^{10-13}$ The main advantages of UF process are: (1) it can be performed isothermally at low temperature with less energy consumption; (2) it offers lower cost; and (3) the ease to scale-up for commercial production. ${ }^{14-16}$ Integration of UF membrane unit with hydrolysis reactor enables continuous removal of glucose and recycling of cellulase enzyme, oligomers sugar and residual cellulose. A key limitation has been noted with the reduction of permeate flux over time in ultrafiltration. These macromolecules especially the polysaccharides and enzymes (proteins) caused the decrease in the permeate flow through the membrane, which can be attributed to the fouling of its surface where the nonpermeating solutes tended to form a gel layer. ${ }^{17,18}$ The permeation characteristics of membranes not only depend on molecular weight of the solutes, but other factors such as charge and hydrophobicity will also affect the permeation of glucose. In addition, since lignocelluloses hydrolysate is a complex mixture, the presence of protein will also lead to fouling arising from specific interaction between protein and membrane. This will also contribute to the reduced glucose permeation and thereby making the separation of fermentable sugars a really challenging process.

Thus, the main objective of this paper is to study and understand the filtration behaviour of the cellulose hydrolysate solutions using three different commercially available UF membranes. The focus will be on the performance of UF membrane and the permeation of glucose that could enable continuous process of enzymatic hydrolysis for cellulose. The influence of solution $\mathrm{pH}$, membrane hydrophobicity and molecular weight cut-off (MWCO) were analysed. 


\section{EXPERIMENTAL}

\subsection{Materials: Chemicals, Membranes and Experiment Rig}

High purity of microcrystalline cellulose (supplied by Sigma Aldrich) was used to prepare the feed solution. The analytical grade glucose, citric acid, tri-sodium citrate were purchased from Nacalai Japan and used as foulant model in the feed solution.

Three different types of UF membrane were used in this work: (1) Polyethersulfone (PES20), obtained from Amfor Inc, USA; (2) Polysulfone (PSF20), purchased from Koch, Germany; and (3) Polyamide (PA3), provided by GE Osmonics, Trisep GMSP, USA. The detailed properties of all membrane are tabulated in Table 1. The contact angle for each membrane was determined in the lab by using contact angle meter (Easy Drop KRÜSS, Gmbh). New membranes were soaked in pure water overnight prior to each run in order to remove the preservative liquids before use.

Table 1: Characteristics of the UF membranes.

\begin{tabular}{|c|c|c|c|}
\hline \multirow{2}{*}{ Characteristics } & \multicolumn{3}{|c|}{ Membrane } \\
\hline & PES20 & PA3 & PSF20 \\
\hline Molecular weight cut-off (MWCO) & $20 \mathrm{kDa}$ & $3 \mathrm{kDa}$ & $20 \mathrm{kDa}$ \\
\hline $\mathrm{pH}$ tolerance ${ }^{\mathrm{a}}$ & $2-13$ & $2-11$ & $2-13$ \\
\hline Hydrophobicity ${ }^{a}$ & Hydrophobic & Hydrophobic & Hydrophobic \\
\hline Contact angle $\left({ }^{\circ}\right)^{\mathrm{b}}$ & 63 & 54 & 73 \\
\hline Zeta potential at $\mathrm{pH} 7(\mathrm{mV})^{\mathrm{b}}$ & -12 & -26 & -11 \\
\hline $\begin{array}{l}\text { Permeability of water at } 2 \mathrm{bar} \\
\text { operating pressure }\left(\mathrm{L} / \mathrm{min} \cdot \mathrm{m}^{2}\right)^{\mathrm{b}}\end{array}$ & 126.24 & 29.18 & 87.93 \\
\hline
\end{tabular}

${ }^{\mathrm{a}}$ Information obtained from manufacturer; ${ }^{\mathrm{b}}$ Value obtained from experimental measurements.

A Sterlitech ${ }^{\mathrm{TM}} \mathrm{HP} 4750$ dead-end stirred cell filtration system with volume capacity of $300 \mathrm{ml}$ with $14.60 \mathrm{~cm}^{2}$ of effective membrane area was used to study the filtration performance as shown in Figure 1. The stirred cell was connected to the nitrogen gas tank which provides the applied pressure to drive the process. 




Figure 1: Schematic diagram of dead-end stirred cell ultrafiltration.

\subsection{Characterisation of Model Cellulose Hydrolysate}

In this study, a model of cellulose hydrolysate was formed by mixing microcrystalline cellulose powder, glucose and cellulose enzymes. The hydrolysate was analysed for molecular weight and isoelectric point (IEP). A $6 \%(\mathrm{w} / \mathrm{w})$ microcrystalline cellulose, $33.3 \mathrm{~g} / 1$ glucose and 8FPU cellulose were added in reverse osmosis water and mixed well for $30 \mathrm{~min}$. Gel electrophoresis in denaturing conditions was performed in sodium dodecyl sulfate (SDS-PAGE) according to the method by Laemmli (1970) resolving gel consisted of $15 \%$ polyacrylamide in Tris-HCl (1.5M, pH 8.8), while stacking gel consisted of $4.5 \%$ polyacrylamide in Tris- $\mathrm{HCl}$ (1.0M, $\mathrm{pH} 6.8) .{ }^{19}$ The sample solutions were mixed at $1: 2(\mathrm{v} / \mathrm{v})$ ratios with the sample buffer and heated at $90^{\circ} \mathrm{C}$ for $3 \mathrm{~min}$ before loading. Aliquots of $40-42$ $\mu 1$ samples were loaded into individual wells and a constant current was passed through the gel for $2 \mathrm{~h}$ to obtain separation of the peptides. Protein markers 10-260 $\mathrm{kDa}$ was used for molecular-weight determination. The gel sheets were stained with Gelcode Blue Safe Protein stain..$^{20}$ As for the determination of isoelectric point (IEP) of cellulose hydrolysate, the zeta potential at a given $\mathrm{pH}$ was recorded by a zeta potential titration apparatus using Malvern Zetasizer Nano ZS, UK. The IEP of the hydrolysate was determined where the zeta potential was zero at the $\mathrm{pH}$ value. The summarised data of cellulose hydrolysate was tabulated in Table 2.

Table 2: Principle characteristics of the celullose hydrolysate.

\begin{tabular}{lc}
\hline Properties & Value \\
\hline pH at room temperature & 4.8 \\
MW distribution from SDS Page & $70 \mathrm{kDa}$ \\
Isoelectric point (IEP) & 3.9 \\
\hline
\end{tabular}




\subsection{Fouling Experiments}

The model cellulose hydrolysate at various $\mathrm{pH}$ values was used as feed solution. Each set of the experiment run was employed with a new membrane disc and compacted with ultrapure water in the dead end stirred cell without stirring effects for $30 \mathrm{~min}$ at 5 bar. In the case of dynamic ultrafiltration test, $300 \mathrm{ml}$ feed solution was conducted under constant pressure at 2 bar for $60 \mathrm{~min}$ with the speed of $500 \mathrm{rpm}$ of stirrer to prevent the formation of series vortex in the cell. The temperature was set at $50^{\circ} \mathrm{C}$ as this was the temperature of the cellulose enzymatic hydrolysis. Permeate flux, $\mathrm{J}\left(\mathrm{L} / \mathrm{m}^{2}, \mathrm{~h}\right)$ was calculated based on the mass/volume (L) of permeate collected on the balance, membrane surface area $\left(\mathrm{m}^{2}\right)$ and filtration time (h) according to Equation 1:

$$
J=\frac{V}{A t}
$$

\subsection{Analytical Methods}

Glucose content was analysed by HPLC (Agilent G1311A) equipped with refractive index $(\mathrm{RI})$ detector and Rezex ROA column $(300 \times 7.80 \mathrm{~mm}) .0 .005 \mathrm{~N}$ $\mathrm{H}_{2} \mathrm{SO}_{4}$ was used as the mobile phase as a flow rate of $0.6 \mathrm{ml} / \mathrm{min}$ and the column temperature was maintained at $60^{\circ} \mathrm{C}$. Enzyme concentration was measured by the Bradford protein assay using bovine serum albumin (BSA) as standard. ${ }^{21}$

\section{RESULTS AND DISCUSSIONS}

\subsection{Pure Water Permeability}

The pure water was filtered using three commercial UF membranes at a pressure range from 1 to 6 . As listed in Table 1, pure water fluxes did not predict the flux behaviour and results of filtrations of the real solution, but it is referred to the membrane weight cut off. ${ }^{22,23}$ The highest pure water flux was obtained with PES20 membrane, resulting from the high molecular weight cut-off of the membrane. Lowest pure water flux was observed for PA3 membrane.

\subsection{Flux Behaviour}

Flux decline behaviours of the three commercial UF membranes of cellulose hydrolysate in stirred batch cell were investigated. The measured membrane flux is presented in Figure 2. The trend of flux decline for PES and PSF membranes 
is similar, about $44 \%$ decreasing. An initial quick flux loss in the first 10 min was followed by a gradual flux decline. This can be explained that in the beginning, the breaking down of microcrystalline cellulose to glucose molecules occurred during hydrolysis process, thus more molecules of glucose blocked the pore of the membranes. Moreover, the particle deposition process followed by protein adsorption on the surface and inside the pores of the membrane caused the formation of cake layer, resulting in extended period of constant flux. However, for PA membrane, only slight decline $(13 \%)$ was observed. The overall flux decline rates follow the order of PSF20 $>$ PES20 $>$ PA3.

The observed trend of membrane flux decline can be explained by the membrane material and properties. The properties of membrane hydrophobicity literally influenced the surface chemistry of the membrane, which may also affect the flux decline during filtration of the solution. Based on the contact angle measurement (Table 1), the hydrophobicity rates of the three commercial UF membranes follow the order of PA3 $>$ PES20 $>$ PSF20, which indicates that the hydrophobicity plays an important role in the preventing foulant adsorption. The hydrophilic membrane has lower interaction with the foulant, which resulted the membrane entirely wetted by the water phase. ${ }^{24}$ On the other hand, PA3 membrane used in this study is the most negatively charged. The hydrophobicity of a surface decreases when more charged groups are present. ${ }^{25}$ The IEP of the solution is 3.9 and the $\mathrm{pH}$ of the solution used in the experiment is $\mathrm{pH} 5$. Higher negative zeta potential should result in less fouling by negatively charged macromolecules due to higher electrostatic repulsion. ${ }^{26}$

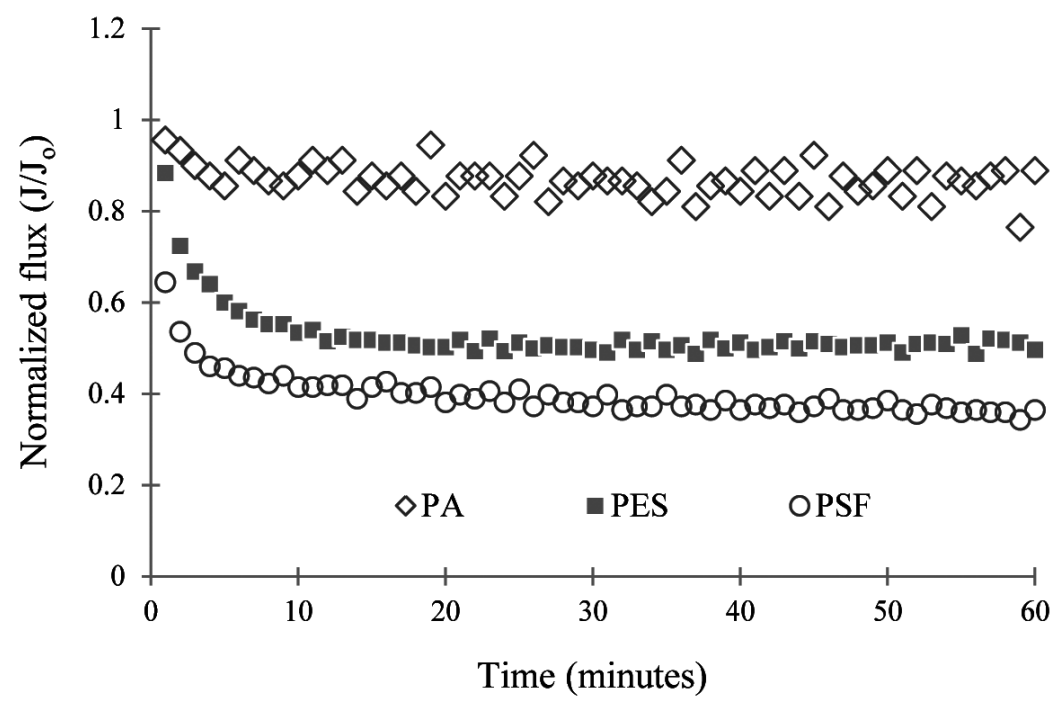

Figure 2: Normalised flux decline of PES, PA and PSF membranes. 


\subsection{Permeation of Glucose and Retention of Enzyme}

The clarification of glucose and retention of enzyme from ultrafiltration cellulose hydrolysate by using three commercial UF membranes was studied. It could be clearly seen (Figure 3 ) that the permeation of glucose was above $95 \%$ for all the UF membranes which augurs well for in-situ recovery of glucose insuring enzymatic hydrolysis. For retention of enzymes, the PA membranes showed the highest retention (100\%) in comparison to the PES and PSF membrane. This is expected since the PA membrane has much lower molecular weight ( $8 \mathrm{kDa})$ as compared to the PES and PSF membranes. It should be noted that the PES and PSF membranes both have $20 \mathrm{kDa}$ MWCO values which should give an almost total rejection for a $70 \mathrm{kDa}$ enzyme. However, the rejection of enzyme was observed to be about $92 \%-93 \%$ only for both membranes. This is similar as reported by Qi et al. and Tang et al. about the recovery of the protein from $74 \%$ to $92 \% .{ }^{27,28}$ A possible explanation for this might be that the adsorptions of the enzyme on the membrane surface that exhibit some of the enzyme passes through the membrane pores. It can be concluded that the PA membrane is superior to PES and PSF membrane in terms of high permeation of glucose, high flux and high antifouling.

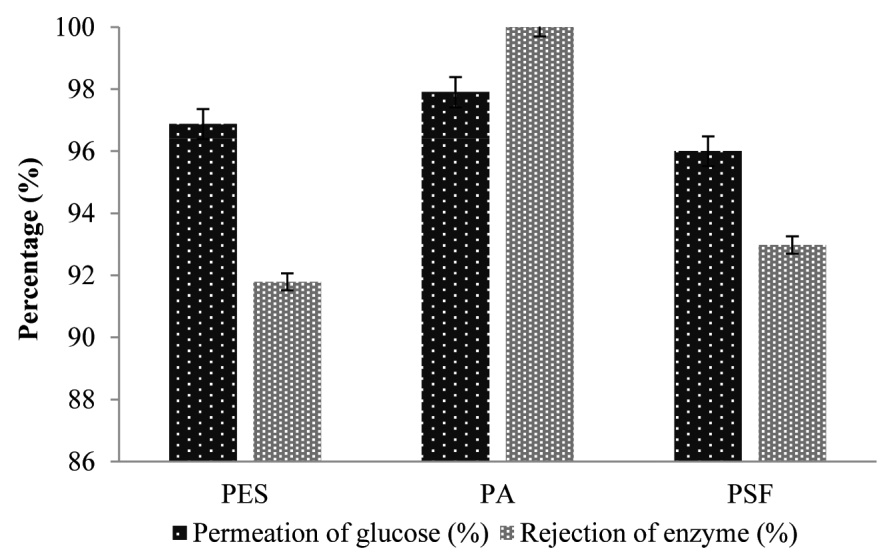

Figure 3: Permeation of glucose and rejection of enzyme.

\subsection{Effect of pH Solution}

During permeation, solutions are exposed to different processing conditions such as interaction with the membrane and the membrane pores' surface. The separation was performed in four different $\mathrm{pH}$ solutions to compare the efficiency of glucose permeation and the fouling behaviour at different $\mathrm{pH}$ conditions. The IEP is thus an important parameter in determining the efficient functioning of the commercial membranes. 
(a)

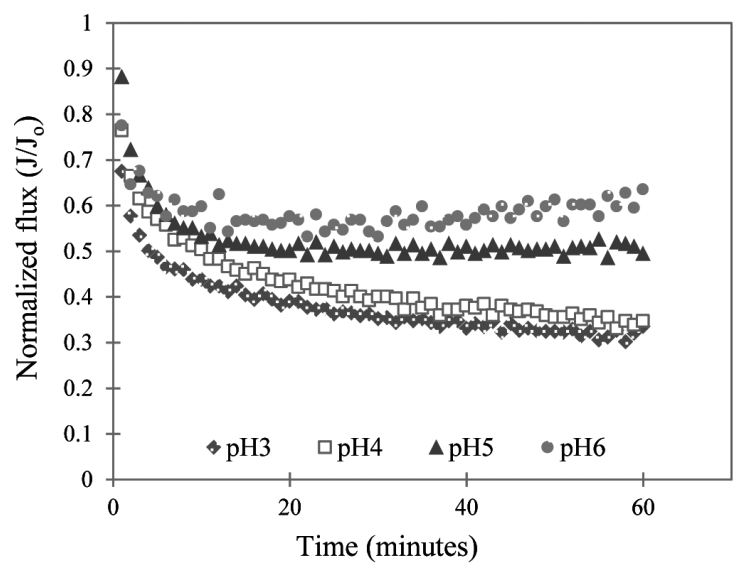

(b)

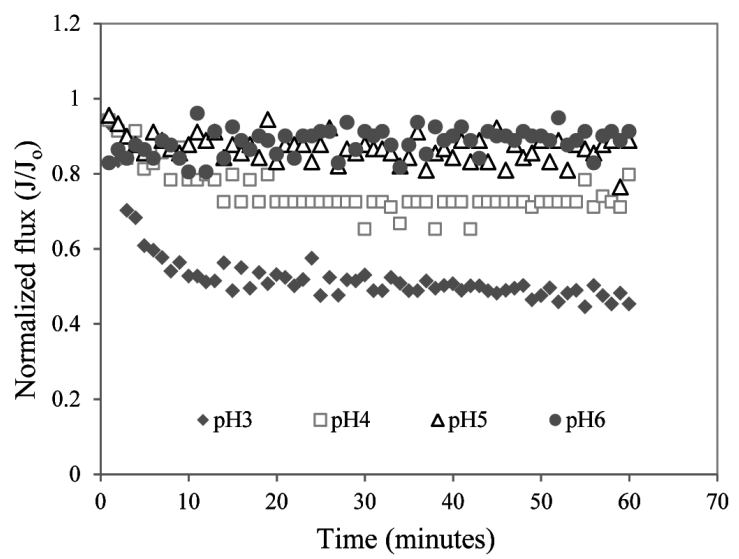

(c)

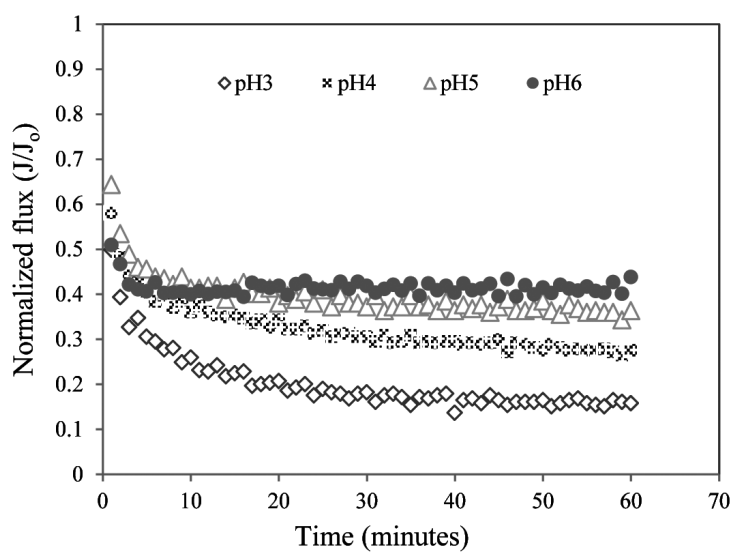

Figure 4: Normalised flux decline of different $\mathrm{pH}$ cellulose hydrolysate solution for (a) PES membrane, (b) PA membrane and (c) PSF membrane. 
Figure 4 shows the membrane flux decline under different $\mathrm{pH}$ solution at $\mathrm{pH} 3,4$, 5 and 6 . The range of $\mathrm{pH}$ values of the solutions selected generally is the tolerance rate of the cellulose enzyme in hydrolysis process. The solution with $\mathrm{pH} 3$ exhibited strong blocking of PES and PSF membrane leading to a significant flux decline. The solution at $\mathrm{pH} 5$ and $\mathrm{pH} 6$ exhibited relatively much higher flux for all the three membranes. It appeared that in acidic $\mathrm{pH}$ where the protein with positive charge in the solution and the negative charge of the membrane surface lead the electrostatic interaction and hence the flux decline. These experimental trends have also been observed by other previous researchers. ${ }^{9,29,30}$

The primary reason for the membrane fouling in these cases could be explained in Figure 5. Below the IEP which is at $\mathrm{pH} \mathrm{3,} \mathrm{both} \mathrm{the} \mathrm{cellulose} \mathrm{hydrolysate}$ solution (positively charged) and PES membranes (negatively charged) have opposite charges, thus the attraction forces are dominant over repulsion forces and subsequently affect the initial flux decline rate at the initial fouling stage. At solution $\mathrm{pH}$ near to IEP $(\sim \mathrm{pH} 4)$, the solubility of a protein built out of amino acids is minimum and has tendency to form aggregates with other molecules. ${ }^{18}$ As the $\mathrm{pH}$ is higher than IEP (raising the $\mathrm{pH}$ to 5 and 6 ), the protein solubility increases and leads lesser accumulation on the membrane surface due to higher electrostatic repulsion. It was confirmed by the observation under SEM (Figure 6) which showed that for PES membrane, accumulation of particles on the membrane surface at $\mathrm{pH} 3$ was much higher compared to that for $\mathrm{pH} 5$.
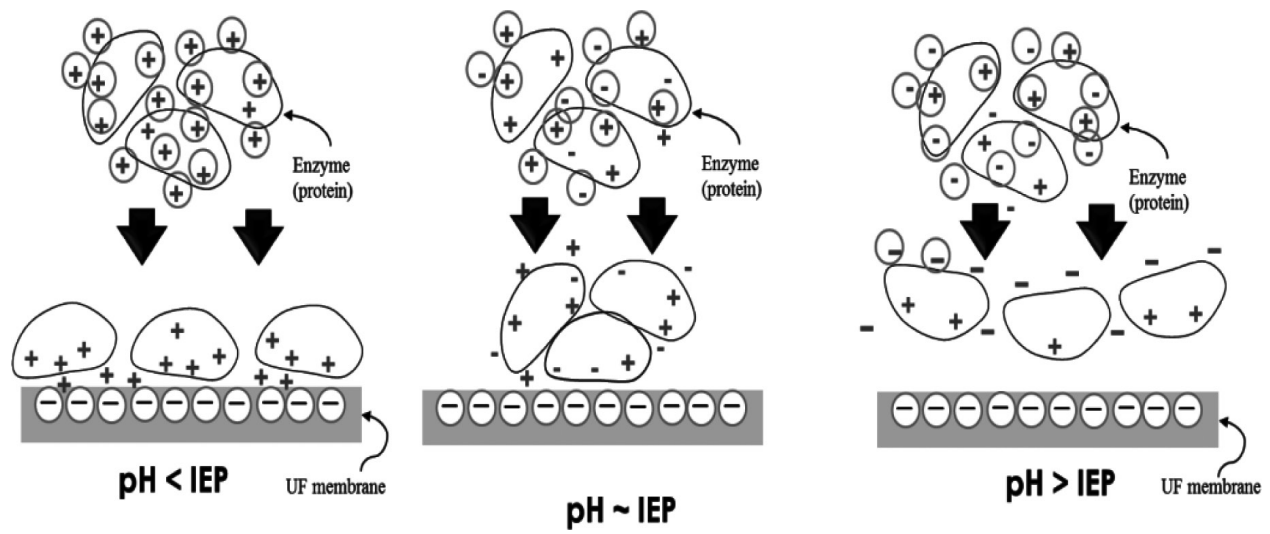

Figure 5: Schematic illustrations of possible configurations of cellulose hydrolysate at $\mathrm{pH}$ lower and higher than IEP. 
(a)

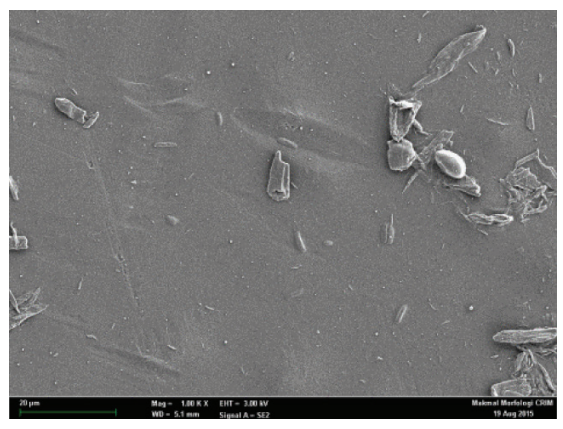

(b)

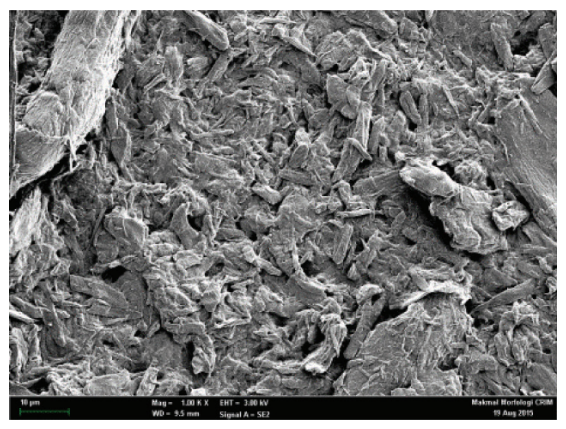

(c)

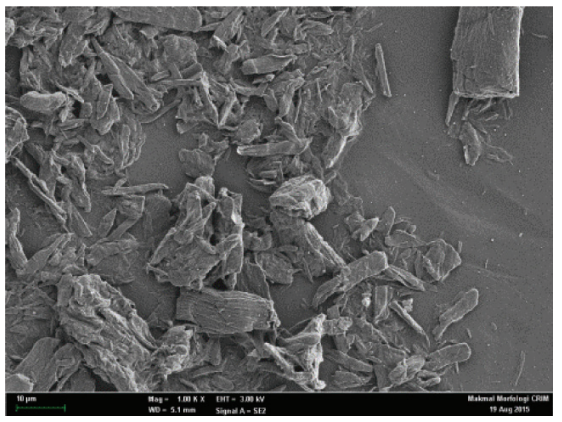

Figure 6: SEM images of PES membranes: (a) clean (b) fouled membrane at $\mathrm{pH} 3$ (c) fouled membrane at $\mathrm{pH} 5$.

\subsection{Contribution of Lignin Loading to Membrane Fouling}

Lignin is considered as one of undesired side products in the effluents after the pre-treatment process and should be preferably retained by membrane. The lignin presence in the cellulosic hydrolysate typically have molecular weights of 1000 2000 Da. ${ }^{31}$ Figure 7 compares the results for the permeation of glucose and retention of enzymes with and without the presence of lignin. The permeation of glucose for solution in the presence of lignin showed similar permeation to that without the presence of lignin. However, the retention of enzyme for PES and PSF membrane was increasing compared to the original solution. A previous work reported that the rejection of lignin is in the range of $2.0 \% \sim 99 \%,{ }^{31}$ which supports the result obtained in this study. Klapiszewski et al. reported that the IEP for the lignin is at $\mathrm{pH} 1 .^{32}$ The retention of enzyme showed an increase due to higher negative charge of the solution, causing higher electrostatic repulsion and lower aggregations of the enzyme. 


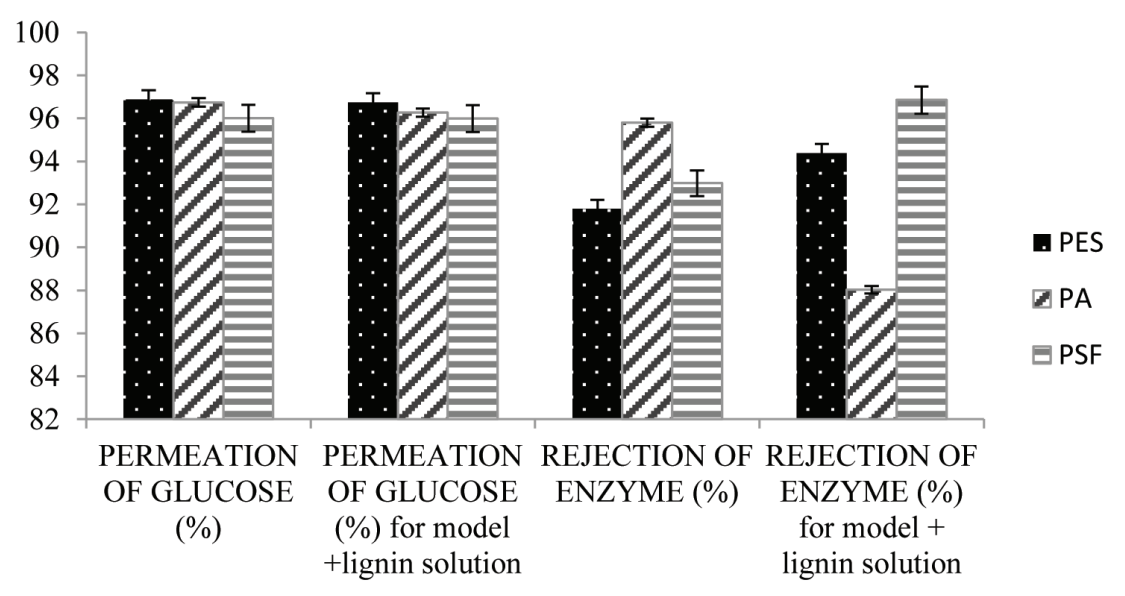

Figure 7: Comparison of glucose permeation and enzyme retention with and without the presence of lignin in cellulose hydrolysate solution.

\section{CONCLUSION}

The screening of three commercial UF membranes in filtering cellulose hydrolysate showed that all three membranes successfully achieved more than $90 \%$ of glucose permeation and enzyme rejection. In comparison to PES20 and PSF20, the membranes exhibited similar flux decline characteristics when removing glucose from cellulose hydrolysate. Meanwhile PA membrane showed a higher flux and better permeation of glucose. It has been shown that solution $\mathrm{pH}$ has significant effect on the extent of cellulose hydrolysate fouling in membrane process. At higher solution $\mathrm{pH}$ ( $\mathrm{pH} 5$ and 6), there was minimum membrane flux decline due to protein-protein and membrane-protein repulsions which minimised aggregation and fouling. At $\mathrm{pH} 5$ of the cellulose hydrolysate solution, PA membrane shows the best performance of anti-fouling, high permeation of glucose and rejection of enzyme.

\section{ACKNOWLEDGEMENTS}

This study was financially supported by the Long-term Research Grant Scheme (LRGS) grant (LRGS/2013/UKM-UKM/PT/03) from Ministry of Higher Education and Universiti Kebangsaan Malaysia. 


\section{REFERENCES}

1. Sindhu, R. et al. (2016). Biological pretreatment of lignocellulosic biomass - An overview. Biores. Technol., 199, 76-82, https://doi.org/10.1016/j. biortech.2015.08.030.

2. Ren, N.-Q. et al. (2016) A review on bioconversion of lignocellulosic biomass to H2: Key challenges and new insights. Biores. Technol., 215, 92-99, https://doi.org/10.1016/j.biortech.2016.03.124.

3. Hossain, M. A. et al. (2016). Prospect of hydrogen production from oil palm biomass by thermochemical process - A review. Int. J. Hydro. Energy, 41(38), 16637-16655, https://doi.org/10.1016/j.ijhydene.2016.07.104.

4. Saini, J. K. et al. (2016). Cellulase adsorption on lignin: A roadblock for economic hydrolysis of biomass. Renew. Energy, 98, 29-42, https://doi.org/ 10.1016/j.renene.2016.03.089.

5. Zabed, H. et al. (2016). Fuel ethanol production from lignocellulosic biomass: An overview on feedstocks and technological approaches. Renew. Sustain. Energy Rev., 66, 751-774, https://doi.org/10.1016/j.rser.2016.08.038.

6. Ma, T., Kosa, M. \& Sun, Q. (2014). Fermentation to bioethanol/biobuthanol. In Ragauskas, A. J. (Ed.). Materials for biofuels,155-185. Georgia: World Scientific.

7. Gautam, A. \& Menkhaus, T. J. (2014). Performance evaluation and fouling analysis for reverse osmosis and nanofiltration membranes during processing of lignocellulosic biomass hydrolysate. J. Membr. Sci., 451, 252-265, https://doi.org/10.1016/j.memsci.2013.09.042.

8. Hwang, K.-J. et al. (2014). Enzymatic hydrolysis suspension cross-flow diafiltration using polysulfone hollow fiber module. J. Membr. Sci., 454, 418-425, https://doi.org/10.1016/j.memsci.2013.12.048.

9. Maiti, S. K. et al. (2012). Modeling of the separation of inhibitory components from pretreated rice straw hydrolysate by nanofiltration membranes. Biores. Technol., 114, 419-427, https://doi.org/10.1016/j.biortech.2012.03.029.

10. Cantarella, M. et al. (2014). Inactivating effects of lignin-derived compounds released during lignocellulosic biomass pretreatment on the endo-glucanase catalyzed hydrolysis of carboxymethylcellulose: A study in continuous stirred ultrafiltration-membrane reactor. Biores. Technol., 156, 48-56.

11. Malmali, M. et al. (2014). Sugar concentration and detoxification of clarified biomass hydrolysate by nanofiltration. Sep. Purific. Technol., 132, 655-665, https://doi.org/10.1016/j.seppur.2014.06.014.

12. Hasar, H. et al. (2004). Production of non-biodegradable compounds based on biomass activity in a submerged ultrafiltration hollow fibre membrane bioreactor treating raw whey. Process Biochem., 39(11), 1631-1638, https://doi.org/10.1016/S0032-9592(03)00299-1. 
13. Zhang, X. et al. (2010). Harvesting algal biomass for biofuels using ultrafiltration membranes. Biores. Technol., 101(14), 5297-5304, https://doi.org/10.1016/j.biortech.2010.02.007.

14. Saxena, A. et al. (2009). Membrane-based techniques for the separation and purification of proteins: An overview. Adv. Colloid Interf. Sci.,145(1), 1-22, https://doi.org/10.1016/j.cis.2008.07.004.

15. Konovalova, V. et al. (2016). Enhanced starch hydrolysis using $\alpha$-amylase immobilized on cellulose ultrafiltration affinity membrane. Carbohydr. Polym., 152, 710-717, https://doi.org/10.1016/j.carbpol.2016.07.065.

16. Zhu, Z. \& Mhemdi, H. (2016). Dead end ultra-filtration of sugar beet juice expressed from cold electrically pre-treated slices: Effect of membrane polymer on fouling mechanism and permeate quality. Innov. Food Sci. Emerg. Technol., 36, 75-82, https://doi.org/10.1016/j.ifset.2016.05.016.

17. Wang, C. et al. (2012). Membrane fouling mechanism in ultrafiltration of succinic acid fermentation broth. Biores. Technol., 116, 366-371, https://doi.org/10.1016/j.biortech.2012.03.099.

18. de Barros, S. T. D. et al. (2003). Study of fouling mechanism in pineapple juice clarification by ultrafiltration. J. Membr. Sci., 215(1-2), 213-224, https://doi.org/10.1016/S0376-7388(02)00615-4.

19. Laemmli, U. K. (1970). Cleavage of structural proteins during the assembly of the head of bacteriophage T4. Nature, 227, 680-685, https://doi.org/ $10.1038 / 227680 \mathrm{a} 0$.

20. Suhimi, N. M., Mohammad, A. W. \& Jahim, J. M. (2013). Production and characterization of hydrolyzed collagen derived from enzymatic hydrolysis of type-B gelatin. Proceeding of the 8th CIGR Section VI International Technical Symposium on Advanced Food Processing and Quality Management.

21. Bradford, M. M. (1976). A rapid and sensitive method for the quantitation of microgram quantities of protein utilizing the principle of protein-dye binding. Anal. Biochem., 72, 248-254, https://doi.org/10.1016/0003-2697 (76)90527-3.

22. Hashino, M. et al. (2011). Effect of kinds of membrane materials on membrane fouling with BSA. J. Membr. Sci., 384(1), 157-165.

23. Ecker, J. et al. (2012). Nanofiltration as key technology for the separation of LA and AA. J. Membr. Sci., 389, 389-398, https://doi.org/10.1016/j. memsci.2011.11.004.

24. Amin, I. N. H. M. et al. (2010). Flux decline study during ultrafiltration of glycerin-rich fatty acid solutions. J. Membr. Sci., 351(1), 75-86, https://doi. org/10.1016/j.memsci.2010.01.033. 
25. Huisman, I. H. et al. (2000). The effect of protein-protein and proteinmembrane interactions on membrane fouling in ultrafiltration. J. Membr. Sci., 179(1), 79-90, https://doi.org/10.1016/S0376-7388(00)00501-9.

26. Li, Q. et al. (2007). Fouling of reverse osmosis membranes by biopolymers in wastewater secondary effluent: Role of membrane surface properties and initial permeate flux. J. Membr. Sci., 290(1), 173-181, https://doi. org/10.1016/j.memsci.2006.12.027.

27. Qi, B. et al. (2012). Application of ultrafiltration and nanofiltration for recycling cellulase and concentrating glucose from enzymatic hydrolyzate of steam exploded wheat straw. Biores. Technol., 104, 466-472, https://doi. org/10.1016/j.biortech.2011.10.049.

28. Tang, D.-S. et al. (2009). Recovery of protein from brewer's spent grain by ultrafiltration. Biochem. Eng. J., 48(1), 1-5, https://doi.org/10.1016/j. bej.2009.05.019.

29. Lim, Y. P. \& Mohammad, A. W. (2012). Influence of $\mathrm{pH}$ and ionic strength during food protein ultrafiltration: Elucidation of permeate flux behavior, fouling resistance, and mechanism. Sep. Sci. Technol., 47(3), 446-454, https://doi.org/10.1080/01496395.2011.627907.

30. Lakra, R. et al. (2013). Separation of acetic acid and reducing sugars from biomass derived hydrosylate using biopolymer blend polyethersulfone membrane. Sep. Purif. Technol., 118, 853-861, https://doi.org/10.1016/j. seppur.2013.08.023.

31. He, Y. et al. (2012). Recent advances in membrane technologies for biorefining and bioenergy production. Biotechnol. Adv., 30(4), 817-858, https://doi.org/10.1016/j.biotechadv.2012.01.015.

32. Klapiszewski, et al. (2013). Preparation and characterization of multifunctional chitin/lignin materials. J. Nanomater., 13, ID 425726, https://doi.org/10.1155/2013/425726. 